\title{
PABRIKASI EDIBLE FILM DARI CARBOXY METHIL CELLULOSE (CMC) DAN MINYAK JAHE SEBAGAI UPAYA PENINGKATAN UMUR SIMPAN ROTI
}

\author{
EDIBLE FILM FABRICATION of CARBOXY METHIL CELLULOSE \\ (CMC) and OIL GINGER as IMPROVING SHELF LIFE BREAD
}

\author{
${ }^{1}$ Mulia W. Apriliyanti, ${ }^{2}$ Ardiyansyah \\ ${ }^{1,2}$ Program Studi Teknologi Industri Pangan Teknologi Pertanian Politeknik Negeri Jember \\ Jalan Mastrip Kotak Pos 164 Jember \\ mulia27apriliyanti@gmail.com
}

\begin{abstract}
Abstrak
Saat ini, industri pengemasan banyak menggunakan bahan yang berbahan dasar plastik. Hal ini mengakibatkan meningkatnya limbah plastik yang susah terurai. Salah satu alternatif solusi adalah penggunaan edible film yang mempunyai beberapa keuntungan, diantaranya adalah dapat melindungi produk, penampakan asli produk dapat dipertahankan, aman bagi lingkungan serta dapat langsung dimakan. Tujuan dari penelitian ini adalah membuat edible film dengan minyak jahe dalam meningkatkan umur simpan roti. Kandungan fenol terbanyak pada konsentrasi minyak jahe 1,5\%, dan ketebalan film tertinggi dengan konsentrasi $1 \%$. Minyak jahe dengan konsentrasi tinggi 2\% memiliki nilai laju tranmsisi uap air paling tinggi yaitu $0,0267 \mathrm{~g} / \mathrm{cm} 2$.jam, hal ini disebabkan molekul minyak atsiri memberi ruang celah-celah rongga atau terpisah dari molekul CMC sehingga CMC mudah berikatan dengan molekul air. Kadar air tertinggi pada konsentrasi minyak jahe $1 \%$, hasil pengamatan secara visual penambahan minyak jahe mampu menekan pertumbuhan jamur sampai 9-14 hari.
\end{abstract}

Kata kunci : edible film, minyak jahe, roti, antimikroba

\begin{abstract}
Currently, many packaging industries using plastic-based materials. This resulted can be increasing of plastic waste that is difficult to degradation. One of alternative solution is the use of edible film which has several advantages, which are able to protect the product, the original appearance of the product can be preserved, biodegradable and can be eaten, The purpose of this study is to make edible film with ginger oil in increasing the shelf life of bread. The highest phenol content with ginger oil concentration of $1.5 \%$, and the highest film thickness with ginger oil concentration of $1 \%$. Ginger oil with a high concentration of $2 \%$ has a water vapor transmission rate value of the highest of $0.0267 \mathrm{~g} / \mathrm{cm}^{2} . \mathrm{h}$. This is caused of essential oils is provide space and separate from molecules CMC. The highest water content with ginger oil concentration of $1 \%$, the results of visual observation, the addition of ginger oil is able to suppress the growth of fungi up to 9 days.
\end{abstract}

Key words : bread, edible film, ginger oils, antimicrobial

\section{PENDAHULUAN}

Kerusakan pada bahan pangan merupakan hal yang dihindari pada bidang industri makanan. Hal tersebut dapat menyebabkan kerugian yang sangat besar diakibatkan gagalnya bidang distribusi. Kerusakan bahan pangan dapat disebabkan oleh beberapa unsur, misalnya kimia, fisika, dan biologi. Salah satu cara untuk mengurangi terjadi kerusakan pada bahan pangan tersebut yaitu dengan metode pengemasan.
Saat ini, industri pengemasan didominasi oleh bahan-bahan pengemas berbahan dasar plastik. Hal ini mengakibatkan meningkatnya limbah plastik di dunia termasuk Indonesia. Parra et al., (2004) menyatakan saat ini sekitar 150 juta ton plastik diproduksi di seluruh dunia setiap tahunnya. Pengemas plastik yang umum digunakan adalah jenis polyethylene, polystirene, polyvinylchloride

dampak yang tidak baik diantaranya merusak lingkungan karena tidak dapat terdegradasi secara biologi, mahal dalam daur ulang dan tercemarnya 
bahan pangan yang dikemas karena adanya zat-zat tertentu yang termigrasi kedalam bahan pangan tersebut.

Salah satu alternatif pemecahannya adalah penggunaan edible film yang mempunyai beberapa keuntungan, diantaranya adalah dapat melindungi produk, penampakan asli produk dapat dipertahankan, aman bagi lingkungan serta dapat langsung dimakan. Edible film yang bersifat antimikroba berpotensi dapat mencegah kontaminasi patogen pada berbagai bahan pangan yang memiliki jaringan (daging, buah-buahan, sayuran). Kombinasi antimikroba dengan pengemas film untuk mengendalikan pertumbuhan mikroba pada makanan dapat memperpanjang masa simpan dan memperbaiki mutu pangan (Quintavalla dan Vicini, 2002).

Beberapa hasil penelitian menunjukkan bahwa edible film yang terbuat dari pati sagu-alginat dengan minyak serai $(0,4 \%)$ dengan aktivitas penghambatan 94,0 + 2,0 mm E.Coli (Maizura et al, 2007). Edible film dari pati dengan minyak serai, cengkeh, kayu manis, sinamaldehida $(0,7 \%)$ mampu menurunkan $\log 4 \mathrm{cfu} / \mathrm{g}$ E.Coli (RojasGrau et al., 2008). Penggunaan edible coating antimikroba yang terbuat dari pati sagu dan minyak sereh dapur mampu memperlama umur simpan paprika selama 33 hari (Miskiyah et al., 2009).

Berdasarkan dari beberapa hasil penelitian tersebut, peneliti tertarik untuk melakukan pabrikasi edible film yang terbuat dari karboksi metil selulosa (CMC) dengan minyak jahe yang diharapkan dapat meningkatkan umur simpan pada roti.

\section{METODOLOGI}

Pelaksanaan penelitian dilakukan di Laboratorium Analisis Pangan Program Studi Teknologi Industri Pangan, Jurusan Teknologi Pertanian, Politeknik Negeri Jember.

\section{A. Bahan dan Alat}

Bahan baku dibutuhkan adalam Carboxy Methyl Selulosa (CMC), aquades, minyak jahe, gliserol, dan tween 80. Alat yang digunakan neraca analitik, corong pisah, hot plate, magnetic stirer.

\section{B. Prosedur Pabrikasi Edible Film}

CMC dengan konsentrasi $2 \%$ dilarutkan dalam aquades $100 \mathrm{ml}$, diaduk menggunakan hot plate dan magnetic stirer dengan suhu $60^{\circ} \mathrm{C}$ selama \pm 20 menit. Kemudian ditambahkan $2 \mathrm{ml}$ gliserol dan diaduk dengan suhu $60^{\circ} \mathrm{C}$ selama +10 menit. Setelah tercampur merata, ditambahkan minyak atsiri jahe $(1 \% ; 1,5 \% ; 2 \%)$ dan Tween $80(0,3 \mathrm{ml})$ dicampur menggunakan magnetic stirer pada suhu $30{ }^{\circ} \mathrm{C}$ selama 6 menit. Dituang pada cetakan plastik yang sudah disterilkan. Didiamkan pada suhu ruang selama \pm 2 hari.

\section{Parameter Pengamatan}

1) Kadar Fenol (AOAC, 2005): Ditimbang sampel 0.5 gram. Kemudian dimasukkan dalam labu ukur volume $250 \mathrm{ml}$, ditambahkan larutan $\mathrm{NaOH} 10 \%$ hingga pH 10, kemudian ditambahkan aquadest hingga tanda batas. Dipipet $25 \mathrm{ml} \mathrm{ke}$ dalam erlenmeyer, dan ditambahkan $20 \mathrm{ml}$ Brom $0,1 \mathrm{~N}$, kemudian ditambahkan $5 \mathrm{ml}$ Asam Klorida dan segera ditutup. Dikocok kuat selama 30 menit. Ditambahkan secara cepat $5 \mathrm{~mL}$ larutan Kalium Iodida, dan ditutup serta dikocok dengan kuat. Kemudian sumbat dibuka dan dibilas dengan sedikit air dan dititrasi dengan Natrium Thiosulfat, yang sebelumnya ditambahkan dengan Indikator Kanji. Titrasi dihentikan sampai warna biru tepat hilang. Blanko menggunakan aquades diperlakukan sama dengan sampel. Rumus kadar fenol dihitung:

(V blanko-Vsampel x N titran x BE fenol)

(mg sampel) $\mathrm{x}$ faktor pengenceran x $100 \%$.

2) Analisa Fisik Edible Film: Analisa ini meliputi ketebalan dan transmisi uap air dari edible film (AOAC, 2005).

3) Analisa kadar air: Analisa kadar air berdasarkan metode AOAC (AOAC, 2005).

4) Uji Penampakan Roti: Sebagai kontrol edible film tanpa penambahan zat mikroba, sedangkan sebagai sampel Minyak atsiri jahe $(1 \% ; 1,5 \% ; 2 \%)$, dilihat perbedaan warna, aroma, dan penampakan visual tumbuhnya jamur.

5) Analisa Data : Faktor yang diteliti dalam penelitian ini adalah penambahan berbagai konsentrasi minyak atsiri jahe yaitu $1 \% ; 1,5 \%$; dan $2 \%$. Rancangan percobaan yang digunakan dalam penelitian ini adalah Rancangan Acak Lengkap (RAL) dengan satu faktor, yaitu variasi konsentrasi minyak atsiri jahe dengan perulangan sampel sebanyak tiga kali dan tiap-tiap sampel dilakukan dua kali ulangan pengujian. Sampel edible film tanpa penambahan minyak atsiri digunakan sebagai kontrol. Data yang diperoleh dianalisa menggunakan ANOVA (Analysis of Varriance). Jika terdapat perbedaan, maka akan dilanjutkan dengan uji tuckey untuk mengetahui ada tidaknya perbedaan pada masing-masing sampel pada tingkat signifikansi $\alpha=0,05$.

\section{HASIL DAN PEMBAHASAN}

\section{A. Kadar Fenol Edible Film}

Kadar fenol yang terdapat dalam edible film dengan variasi konsentrasi minyak jahe $1 \%, 1,5$ $\%, 2 \%$. Kadar fenol tertinggi didapat pada minyak jahe $1,5 \%$ yaitu $40 \%$, kemudian terjadi penurunan kandungan fenol $2 \%$ menjadi $2,17 \%$, dikarenakan minyak atsiri jahe banyak yang menguap karena tidak terikat kuat dengan edible film dari CMC yang dihasilkan dengan perbandingan 1:1. Kadar fenol edible film dari CMC dengan variasi konsentrasi minyak jahe tersaji dalam Tabel 1. 
TABEL I

KADAR FENOL EDIBLE FILM CMC DENGAN VARIASI KONSENTRASI MINYAK JAHE

\begin{tabular}{|c|c|}
\hline Perlakuan Minyak Jahe (\%) & Kadar Fenol (\%) \\
\hline 1 & 33,78 \\
\hline 1,5 & 40,09 \\
\hline 2 & 2,17 \\
\hline
\end{tabular}

\section{B. Kadar Air}

Kadar air bahan edible film dengan perbedaan konsentrasi minyak jahe tidak memberikan perbedaan yang nyata dari analisis ragam. Kadar air tertinggi pada minyak jahe $1 \%$ adalah $31,32 \%$. Kadar air edible film dari CMC dengan variasi konsentrasi minyak jahe tersaji dalam Tabel 2 berikut.

TABEL II. KADAR AIR EDIBLE FILM CMC DENGAN VARIASI KONSENTRASI MINYAK JAHE

\begin{tabular}{|c|c|}
\hline Perlakuan Minyak Jahe (\%) & Kadar Air (\%) \\
\hline 1 & 31,32 \\
\hline 1,5 & 27,15 \\
\hline 2 & 30,61 \\
\hline
\end{tabular}

\section{Ketebalan Edible Film}

Ketebalan edible film dengan bertambahnya konsentrasi minyak jahe semakin tipis hal ini mungkin disebabkan minyak jahe banyak yang menguap dan tidak merata dalam mencetak. Ketebalan edible film dari CMC dengan variasi konsentrasi minyak jahe tersaji dalam Tabel 3.

TABEL III. KETEBALAN EDIBLE FILM CMC DENGAN VARIASI KONSENTRASI MINYAK JAHE

\begin{tabular}{|c|c|}
\hline Perlakuan Minyak Jahe $\mathbf{( \% )}$ & Ketebalan $(\mathbf{m m})$ \\
\hline 1 & 0,29 \\
\hline 1,5 & 0,1 \\
\hline 2 & 0,14 \\
\hline
\end{tabular}

Ket : analisis ragam perlakuan berbeda nyata $(p<0,05)$

\section{Laju Transmisi Uap Air}

Laju transmisi uap air merupakan salah satu sifat paling penting dalam edible film, karena dapat digunakan untuk mengetahui nilai permeabilitas suatu bahan terhadap air. Umumnya edible film yang terbuat dari polisakarida memiliki permeabilitas uap air yang relatif tinggi karena sifat hidrofilik. Selain itu, permeabilitas uap air edible film hidrofilik akan meningkat seiring dengan peningkatan ketebalan film. Minyak atsiri dengan konsentrasi tinggi 2\% memiliki nilai laju tranmsisi uap air paling tinggi yaitu 0,0267 $\mathrm{g} / \mathrm{cm} 2$.jam, hal ini disebabkan molekul minyak atsiri memberi ruang celah-celah rongga atau terpisah dari molekul CMC sehingga CMC mudah berikatan dengan molekul air. Minyak jahe dengan konsentrasi $1 \%$ memiliki nilai terendah dikarenakan molekul minyak atsiri mampu mengisi rongga rantai polimer $\mathrm{CMC}$ sehingga mampu menahan laju permeabilitas uap air. Laju transmisi edible film dari CMC dengan variasi konsentrasi minyak jahe ditampilkan pada Gambar 1. berikut.

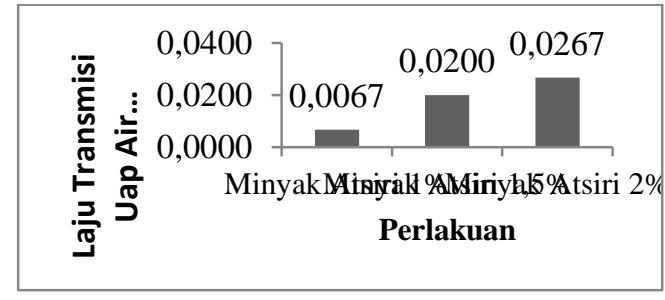

Gambar1. Histogram perlakuan terhadap laju tranmisi uap air

Ket : analisis ragam perlakuan tidak berbeda nyata $(\mathrm{p}>0,05)$

\section{E. Penampakan Visual Roti}

Edible film dengan berbagai konsentrasi minyak jahe $(1 ; 1,5 ; 2 \%)$ ternyata mampu meningkatkan umur simpan dari roti. Pengamatan dimulai ketika batas kadaluarsa roti tersebut. Umumnya roti tawar memiliki umur simpan 7 hari, setelah dilapisi edible film dari minyak jahe ternyata mampu meningkatkan umur simpan sampai 9 hari setelah masa kadaluarsa yang ditentukan. Pengamatan visual aplikasi edible film dari CMC dengan variasi konsentrasi minyak jahe ditampilkan pada Gambar 2 dan 3.

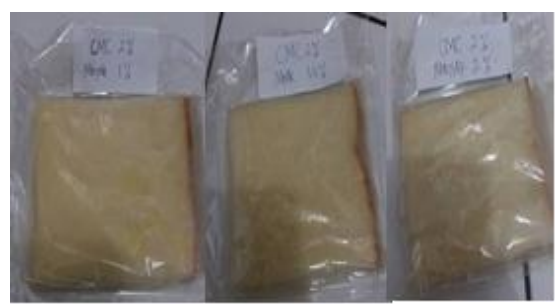

Gambar 2. Pengamatan Visual : Penyimpanan hari ke-9 Dilapisi Edible Film dengan Minyak Jahe

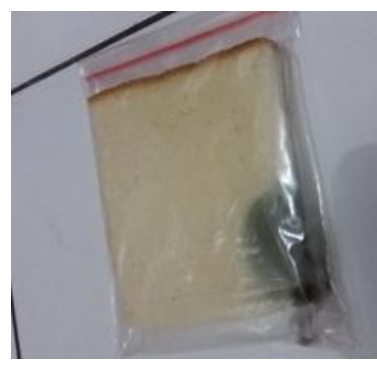

Gambar 3. Pengamatan Visual : Penyimpanan hari ke- 9 Tanpa Dilapisi Edible Film dengan Minyak Jahe

\section{KESIMPULAN}

Kandungan fenol terbanyak pada konsentrasi minyak jahe $1,5 \%$, dan ketebalan film tertinggi dengan konsentrasi $1 \%$. Minyak atsiri dengan konsentrasi tinggi $2 \%$ memiliki nilai laju tranmsisi uap air paling tinggi yaitu $0,0267 \mathrm{~g} / \mathrm{cm} 2$.jam, hal ini disebabkan molekul minyak atsiri memberi ruang celah-celah rongga atau terpisah dari molekul CMC sehingga CMC mudah berikatan dengan molekul air. Kadar air tertinggi pada konsentrasi $1 \%$, hasil pengamatan secara visual penambahan minyak jahe mampu menekan pertumbuhan jamur sampai 9 hari. 
Mulia W Apriliyanti, Ardiyansyah, Pabrikasi Edible Film dari Carboxy Methil Cellulose (CMC) dan Minyak Jahe Sebagai Upaya Peningkatan Umur Simpan Roti

\section{UCAPAN TERIMA KASIH}

Kami sampaikan terima kasih kepada pihak Politeknik Negeri Jember, khususnya Pusat Penelitian dan Pengabdian pada Masyarakat (P3M) yang telah menyelenggarakan dan mendanai program ini melalui Program Penelitian dan Pengabdian pada Masyarakat Sumber Dana BOPTN Tahun 2016.

\section{DAFTAR PUSTAKA}

[1] Ali, B.H., G. Blunden, M. O. Tanira dan A. Nemmar. 2008. Some phytochemical, pharmacological and toxicological properties of ginger (Zingiber officinale Roscoe): A review of recent research. Food and Chemical Toxicology. $46: 409-420$

[2] Bartley, J. dan A. Jacobs. 2000. Effects of drying on flavour compounds in Australian-grown ginger (Zingiber officinale). Journal of the Science of Food and Agriculture. 80:209-215.

[3] Bonilla J, Atares L, Chiralt A. 2012. Edible films and coatings to prevent the detrimental effect of oxygen on food quality: Possibilities and limitations. JFood Eng 110:208-213.

[4] Denyer, C.V., P. Jackson, D.M. Loakes, M.R. Ellis dan D.A.B. Yound. 1994. Isolation of antirhinovira sesquiterpenes from ginger (Zingiber officinale). J Nat Products. 57 : 658-662.

[5] Harris H. 1999. Kajian teknik formulasi terhadap karakteristik edible film dari pati ubi kayu, aren dan sagu untuk pengemas produk pangan semi basah. [tesis] Bogor: Program Pascasarjana, Institut Pertanian Bogor

[6] Hernani dan E. Hayani. 2001. Identification of chemica components on red ginger (Zingiber officinale var. Rubrum) by GC-MS. Proc. International Seminar on natural products chemistry and utilization of natura resources. UI-Unesco, Jakarta : 501-505

[7] Karbowiak T, Debeaufort F, Champion D, Voilley A. 2006. Weetingn properties at the surface of iotacarrageenan-based edible films. $J$ of Colloid and IntSci 294:400-410.

[8] Maizura, M., A. Fazilah, M.H. Norziah, and A.A. Karim. 2007. Antibacterial activity and mechanical properties of partially hydrolyzed sago starch-alginate edible film containing lemongrass oil. J. Food Sci. 72: 6: c324-c330.

[9] Mindarwati M. 2006. Kajian pembuatan edible film komposit dari karagenan sebagai pengemas bumbu mie instant rebus. [tesis]. Bogor: Program Pascasarjana, Institut Pertanian Bogor.
[10] Miskiyah, Widaningrum, dan C. Winarti. 2009 Formulasi dan aplikasi edible coating pada paprika (Capsicum annum) untuk meningkatkan masa simpan minimal 10 hari. Laporan Akhir Tahun. Balai Besar Penelitian dan Pengembangan Pascapanen Pertanian, Bogor. $70 \mathrm{hlm}$

[11] Mustafa, T. dan K.C. Srivastava. 1990. Ginger (Zingiber officinale) in migraine headache. J. Ethnopharmacol. 29 : 267-273.

[12] Navam S, Hettiarachychy, Eswaranandam S. 2005. Edible Films and Coatings from Soybean and Other Protein Sources. University of Arkansas.Fayetteville, Arkansas.

[13] Nwinuka, N., G. Ibeh dan G. Ekeke. 2005. Proximate composition and levels of some toxicants in four commonly consumed spices. J. Appl. Sci. Environ. Mgt. 9: $150-155$.

[14] Odebunmi, E., O. Oluwaniyi dan M. Bashiru. 2010. Comparative proximate analysis of some food condiments. J. App. Sci. Res. 6: 272-274.

[15] Osorio AF, Molina P, Matiacavich S, Enrione J, Skurtys O. 2011. Characteristics of hydroxy propyl methyl cellulose (HPMC) based edible film developed for blueberry coatings. Procedia Food Sci 1:203-209.

[16] Parra DF, Tadini CC, Ponce P, Lugao AB. 2004. Mechanical properties and water vapor transmission in some blends of cassava starch edible films. Carbohydrate Polymers 58:475-481.

[17] Parris N. David RC, Remon JF, Helmut P. 1995. Composition factors affecting the water vapour permeability and tensile properties of hydrophilic films, JAgri Food Chem. 43(6):1432-1435.

[18] Pranoto, Y., V.M. Salokhe, and S.K. Rakshit. 2005. Physical and antibacterial properties of alginate-based edible film incorporated with garlic oil. J. Food Res. Intl. 38: 267-272.

[19] Quintavalla, S. and L. Vicini. 2002. Antimicrobial food packaging in meat industry. Meat Sci. 62: 373-380.

[20] Rojas-Grau, M.A., M.S. Tapia, and O. Martin-Belloso. 2008. Using polysaccharide-based edible coating to maintain quality of freshcut Fuji apples. LWT 41: 139-147.

[21] Tapsell, L.C., I. Hemphill, L. Cobiac, C.S. Patch, D.R Sullivan, M. Fenech, S. Roodenrys, J.B. Keogh, P.M. Clifton, P.G. Williams, V.A. Fazio dan K.E. Inge. 2006. Health benefits of herbs and spices: the past, the present, the future. Med. J. Aust. 185 (Suppl. 4),S4-S24.

[22] Wang, W.H. dan Z.M. Wang. 2005. Studies of commonly used traditional medicine-ginger. Zhongguo Zhong Yao Za Zhi. 30:1569-1573. 